\title{
Profil Kepribadian Big Five dan Collecting Behaviour Kolektor Piringan Hitam
}

\author{
Eni Nuraeni Nugrahawati, Destianty Arista \\ Universitas Islam Bandung, Jl. Taman Sari Bandung \\ e-mail: enipsikologi@gmail.com
}

\begin{abstract}
A collector has peculiarities in their behavior, they have an emotional bond with his collection, persistent in hunting collection and preserved in caring, worried about the loss and damage of his/her collections. This study focused on how the collector's personality profile and behavior on collecting records by using the theory of the Big Five Personality Profile from McIntosh \& Schmeichel. The subjects of research were collector of records aged 30 to 39 years old with the level of social status was medium. By factors analysis through International Item Pool Representation (IPIP-NEO) questionnaire from Goldberg, this research found that type personality mostly were the openess to experience was high, Counscientiousness was high, Extraversion was high, Agreeableness was high, and Neuroticsm was low ( $\mathrm{O} \uparrow \mathrm{C} \uparrow \mathrm{E} \uparrow \mathrm{A} \uparrow \mathrm{N} \downarrow)$. Additionally the Collecting Behaviour type were the Passionate was high, the Inquisitive was low, the Hobby was high and the Expressive was high $(\mathrm{P} \uparrow \mathrm{I} \downarrow \mathrm{H} \uparrow \mathrm{E} \uparrow)$.
\end{abstract}

Keywords: Big Five personality, collecting behaviour, records collector

\begin{abstract}
Abstrak
Seorang kolektor memiliki kekhasan dalam perilakunya, mereka memiliki ikatan emosional dengan koleksinya, gigih dalam berburu koleksi dan tekun dalam merawat, cemas akan kehilangan dan kerusakan koleksi. Penelitian ini melihat bagaimana profil kepribadian dan collecting behaviour pada kolektor piringan hitam dengan menggunakan teori Profil Kepribadian Big Five dari McIntosh \& Schmeichel. Subjek penelitiannya kolektor piringan hitam yang berusia 30-39 tahun dengan status sosial menengah. Setelah dilakukan analisis faktor dengan menggunakan kuesioner International Item Pool Representation (IPIP-NEO) yang disusun oleh Goldberg, diketahui tipe yang paling banyak muncul adalah trait Openess to experience tinggi, Counscientiousness tinggi, Extraversion tinggi, Agreeableness tinggi, dan Neuroticsm rendah $(\mathrm{O} \uparrow \mathrm{C} \uparrow \mathrm{E} \uparrow \mathrm{A} \uparrow \mathrm{N} \downarrow)$. Selain itu didapatkan tipe Collecting Behaviour yaitu tipe Passionate tinggi, Inquisitive rendah, Hobby tinggi dan Expressive tinggi ( $\mathrm{P} \uparrow \mathrm{I} \downarrow \mathrm{H} \uparrow \mathrm{E} \uparrow)$.
\end{abstract}

Kata Kunci: Big Five personality, collecting behaviour, kolektor piringan hitam

\section{Pendahuluan}

Musik merupakan seni yang melukiskan pemikiran dan perasaan manusia melalui keindahan suara. Dimanapun manusia berada, kegiatan mendengarkan musik merupakan kegemaran tersendiri dengan menggunakan media yang berbeda-beda. Media untuk mendengarkan musik terus berkembang dari masa ke masa. Media pemutar musik pertama berbentuk piringan hitam. Di Indonesia sendiri, piringan hitam mulai digunakan sebagai media untuk mendengarkan musik sekitar tahun 1957. Dengan berjalannya waktu, berkembang pula teknologi media pemutar musik yang semakin canggih. Perkembangannya dimulai sejak media pemutar musik Era Analog, merupakan musik yang dapat didengar dan dinikmati dengan menggunakan teknologi lain, misalnya piringan hitam, kaset ataupun CD. Setelah teknologi semakin berkembang, saat ini media pemutar musik memasuki Era Digital.

Sekalipun dalam era digital, namun masih ada orang yang menggemari untuk mendengarkan musik melalui media piringan hitam. Piringan hitam memiliki kelebihan, seperti suara yang lebih jernih dan berkualitas bagus jika menggunakan jarum yang benar dibandingkan dengan 
media lain dan musik dalam bentuk file. Piringan hitam lebih tahan lama, memiliki cover yang menarik dan besar, dan dapat didengarkan walaupun tidak ada listrik dengan menggunakan gramofon. Selain itu nilai tambah untuk yang mempunyai piringan hitam sekarang ini adalah kepuasan batin, gengsi, dan esensinya dalam mengoleksi barang.

Karena piringan hitam merupakan barang ekslusif dan mahal, maka tidak semua orang dapat memilikinya. Namun ada kolektor piringan hitam yang memiliki sampai ribuan keping piringan hitam. Berbagai cara dilakukan kolektor untuk mendapatkan dan melengkapi koleksinya dengan mengesampingkan kebutuhan yang dianggap penting terutama pada kolektor usia dewasa muda (30-40 tahun) yang sudah berkeluarga dan memiliki anak. Mengoleksi merupakan topik utama dalam perselisihan rumah tangga kolektor, juga dianggap sebagai kegiatan kekanakkanakan, yang menimbulkan tambahan anggaran kebutuhan berlebih dalam kehidupan rumah tangga.

Piringan hitam sendiri mulai banyak digunakan dan hampir semua musisi mengeluarkan albumnya berupa piringan hitam pada era 60 -an. Hal tersebut berarti bahwa piringan hitam bukanlah media yang familiar digunakan oleh usia dewasa muda 30-40 tahun saat ini. Namun kolektor usia dewasa muda ini sangat mengerti dan menyukai segala sesuatu yang berkaitan dengan piringan hitam.

Berdasarkan observasi terhadap 20 kolektor piringan hitam, diperoleh bahwa perilaku yang ditampilkan oleh kolektor dewasa adalah orang yang menghabiskan lebih banyak waktu untuk aktivitas yang disenangi yaitu mengoleksi piringan hitam. Diketahui sebanyak 18 orang senang bertualang ke berbagai daerah dalam kegiatannya memburu koleksi. Kolektor menyukai segala aktivitas yang berkenaan dengan piringan hitam, seperti aktivitas memburu piringan hitam ke berbagai daerah, pelosok bahkan sampai ke luar negeri. Diketahui pula sebanyak 7 orang kolektor merasa cemas dan gelisah ketika koleksi yang mereka inginkan belum diperoleh karena takut piringan hitam tersebut dibeli orang lain. Kolektor piringan hitam juga mudah tergugah secara emosional karena sangat menghargai makna dari segala sesuatu hal. Selain itu sebanyak 20 kolektor piringan hitam sangat memperhatikan koleksinya, mereka menyusun dan menata piringan hitam berdasarkan abjad, genre musik atau tahun dibelinya piringan hitam tersebut. Kolektor gigih dalam memburu piringan hitam dengan mencari informasi dari jejaring internet maupun dari mulut ke mulut.

Perilaku-perilaku tersebut merupakan kecenderungan umum para kolektor sesuai dengan kepribadian kolektor piringan hitam. Perilaku-perilaku yang ditampilkan dan diekspresikan oleh kolektor piringan hitam dalam situasi mengoleksi tersebut diasumsikan sesuai dengan faktor-faktor yang terdapat pada Faktor Lima Besar menurut McCrae dan Costa. Faktor lima besar tersebut terdiri atas Neuroticsm (N), Extraversion (E), Openess (O), Agreeableness (A), Conscientiousness (C). Dari ke lima faktor tersebut dapat dieja OCEAN (John, 1990:96). Dalam teori lima faktor, sifat diperlakukan sebagai sesuatu yang benar-benar eksis, setiap faktor dipandang sebagai struktur psikologis yang dimiliki oleh setiap orang dalam tingkatan yang bervariasi (Pervin, 2003).

Perilaku-perilaku yang ditampilkan oleh kolektor piringan hitam tersebut termasuk kedalam Collecting Behaviour. McIntosh \& Schmeichel mendefinisikan perilaku mengoleksi sebagai "perilaku yang memiliki motivasi untuk mengumpulkan serangkaian objek yang sama yang mana fungsi instrumental dari objek menjadi perhatian sekunder (atau tidak), dan orang tersebut tidak berencana untuk segera membuang benda-benda tersebut." (McIntosh \& Schmeichel, 2004:86). Keputusan seorang kolektor untuk mengoleksi dan kategori objek yang dipilih 
tumbuh berdasarkan kepribadian, kepentingan, motivasi dan pengalaman.

Berdasarkan uraian diatas, peneliti tertarik untuk meneliti mengenai Profil Kepribadian Big Five dan Collecting Behaviour pada kolektor piringan hitam. Gunanya dapat menjadi referensi dan menambah wawasan bagi peneliti lain di bidang psikologi, khususnya tentang profil kepribadian dan collecting behaviour pada kolektor piringan hitam.

The Big Five Factor atau Five Factor Model Personality (FFM) merupakan salah satu bentuk teori dari kepribadian trait. Teori ini merupakan bentuk organisasi dari hirarki kepribadian seseorang. The big five factor melihat kepribadian manusia melalui lima trait besar menurut McCrae \& Costa (2003) yaitu extraversion, neuroticsm, openess, agreeableness, dan concientousness.

Collecting Behaviour menurut McIntosh \& Schmeichel (2004), merupakan perilaku yang memiliki motivasi untuk mengumpulkan serangkaian objek yang sama dimana fungsi instrumental dari objek menjadi perhatian sekunder (atau tidak), dan orang tersebut tidak berencana untuk segera membuang benda-benda tersebut. Terdiri atas 4 (empat) tipe yaitu passionate, inquisitive, hobby dan expressive.

\section{Metode Penelitian}

Penelitian mengenai profil kepribadian big five dan collecting behaviour pada kolektor piringan hitam ini merupakan penelitian deskriptif. Artinya sebagai suatu penelitian yang berusaha mendeskripsikan suatu fenomena/peristiwa secara sistematis secara apa adanya. Teknik sampling menggunakan accidental sampling dan diperoleh sebanyak 18 kolek-tor yang memenuhi karakteristik yang telah ditentukan. Alat ukur yang digunakan, yaitu alat ukur kepribadian The Big Five dari International Item Pool Representation (IPIP-NEO) yang disusun oleh Goldberg (1992) dan alat ukur collecting behaviour berdasarkan tipe perilaku mengoleksi yang dijelaskan oleh McIntosh \& Schmeichel (2004). Untuk menguji validitas menggunakan teknik korelasi rank Spearman. Sementara itu untuk nilai reliabilitas berdasarkan Alpha Cronbach diperoleh sebesar 0.892 untuk Profil Kepribadian Big Five dan sebesar 0.948 untuk Collecting Behavior.

\section{Hasil Penelitian dan Pembahasan}

\section{Profil Kepribadian Big Five}

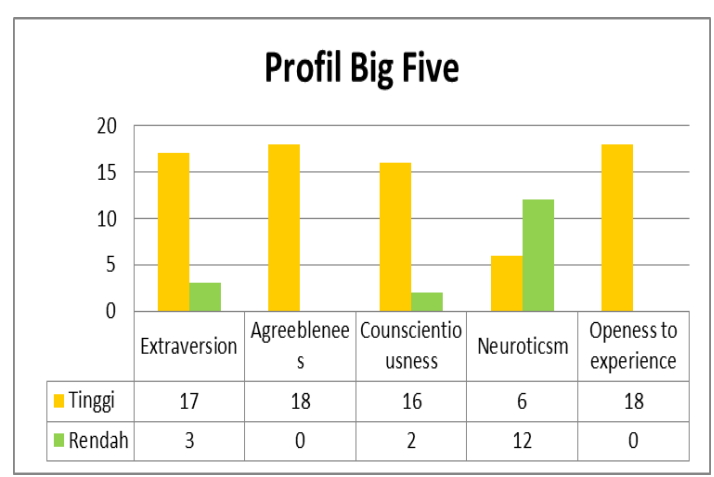

Gambar 1. Profil kepribadian Big Five kolektor piringan hitam.

Berdasarkan gambaran profil kepribadian Big Five tersebut didapatkan 5 tipe kepribadian Big Five disertai penggolongan kriteria tinggi dan rendah pada setiap tipenya.

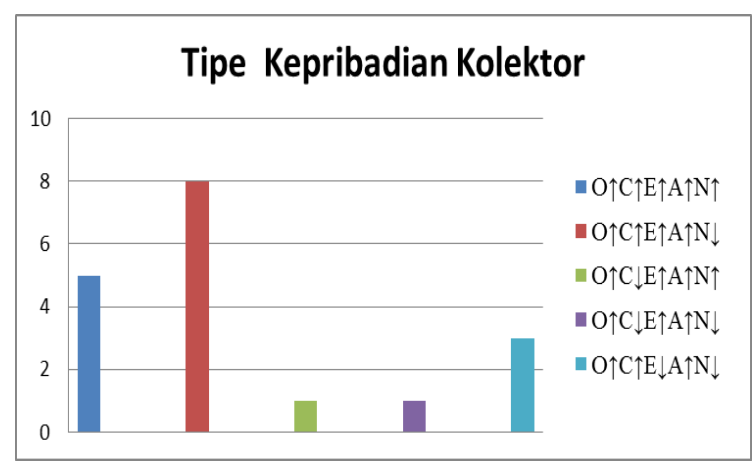

Gambar 2. Penyebaran tipe kepribadian Big Five. 


\section{Tipe Collecting Behaviour}

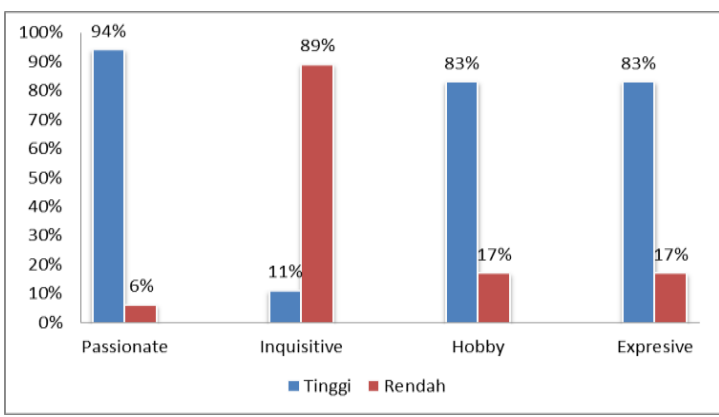

Gambar 3. Tipe collecting behaviour Kolektor Piringan Hitam.

Berdasarkan gambaran Collecting Behaviour tersebut didapatkan 16 tipe Collecting Behaviour disertai penggolongan kriteria tinggi dan rendah pada setiap tipenya.

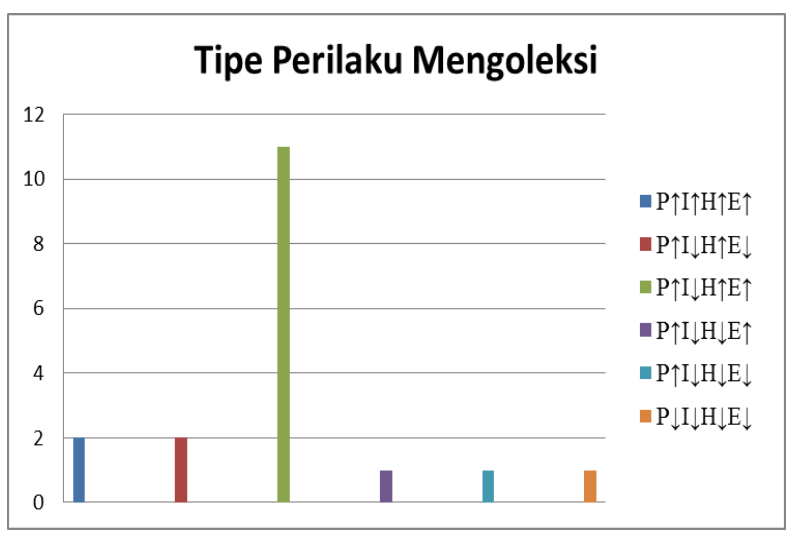

Gambar 4. Tipe perilaku mengoleksi kolektor piringan hitam.

\section{Berdasarkan Data Demografi}

Berdasarkan hasil penelitian ini diketahui bahwa rentang usia kolektor piringan hitam berada diantara usia 30-39 tahun. Berdasarkan penelitian sebelumnya (Danet \& Katriel 1988) mengoleksi lebih luas di kalangan anak-anak daripada orang dewasa. Alasan mengapa banyak remaja berhenti mengoleksi dan hanya sedikit orang dewasa kembali ke aktivitas ini dirumuskan menjadi tiga alasan yaitu: rasa takut akan penilaian orang lain ketika terlibat dalam hobi kekanak-kanakan (Kozden 1989), kurangnya waktu luang untuk mengoleksi, dan meningkatnya sejumlah kemungkinan alternatif mencapai kesadaran akan kepiawaian sebagai individu dewasa (Belk et al. 1991). Pada kolektor piringan hitam, usia produktif tidak menghalangi mereka untuk selalu mencari kepuasan secara pribadi. Pekerjaan mereka tidak menghalangi aktivitasnya dalam mengoleksi, dalam Hurlock (1980) menyatakan bahwa beberapa minat yang dipertahankan orang dewasa tidak sesuai dengan peran orang dewasa (tidak lagi hanya mengejar kepuasan) dan biasanya pada dewasa dini terjadi pergeseran terhadap bobot minat yang mana hal tersebut tidak dialami oleh kolektor piringan hitam.

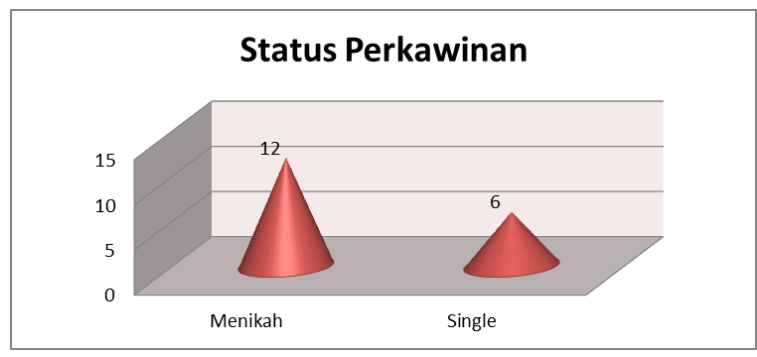

Gambar 5. Status perkawinan kolektor piringan hitam.

Berdasarkan grafik di atas diketahui bahwa 12 dari 18 kolektor sudah menikah. Menurut Hurlock (1980:254), orang dewasa yang telah menikah dan menjadi orang tua, umumnya tidak mempunyai waktu, uang dan tenaga untuk melanjutkan kesukaan atau minat saat remaja. Orientasi pada kehidupan keluarga menggantikan orientasi pada diri pribadi. Namun kolektor piringan hitam masih sangat menyukai aktivitas-aktivitas yang menimbulkan kepuasan secara pribadi. Sebanyak 9 ( ehavior) dari 12 kolektor yang menikah sudah memiliki anak. Hal tersebut menggambarkan bahwa peran mereka sudah berubah menjadi orang tua dan memiliki tanggungan dan perhatian bukan hanya kepada pasangan tetapi juga kepada anaknya. Namun mereka masih memper- 
tahankan aktivitas mengoleksi mereka dan menambah anggaran tambahan selain untuk kebutuhan keluarga.

Berdasarkan hasil analisis ehavi kebanyakan kolektor piringan hitam memiliki profil kepribadian tipe $\mathbf{O} \uparrow \mathbf{C} \uparrow \mathbf{E} \uparrow \mathbf{A} \uparrow \mathbf{N} \downarrow$. Openess to experience tinggi menggambarkan kolektor yang senang mengeksplorasi hal-hal yang tidak umum seperti mengoleksi piringan hitam. Kolektor memiliki kesenangan terhadap aktivitas aesthetics dan senang dengan segala sesuatu yang terlihat indah. Salah satunya piringan hitam dengan bentuk fisik dan cover yang menarik dan jarang ada pada media ehav lainnya. Selain itu ehavior tinggi didukung dengan pernyataan Meyers (1958:562), bahwa mengoleksi ditempatkan pada area pengalaman yang meliputi fantasi, kreativitas, play dan imajinasi. Pada saat mendengarkan piring-an hitam, kolektor membayangkan hal-hal yang mengantarkan ke masa dimana piring-an hitam dibuat. Selain itu kolektor memiliki ide-ide yang tidak biasa dalam kegiatannya mengoleksi, berburu koleksi sampai ke pelosok dan mencari informasi yang berkaitan dengan benda koleksinya. Kualitas-kualitas tersebut yang membuat kolektor unik dan berbeda dari orang secara umum.

Trait ehavior to experience tinggi yang dimiliki kolektor berkaitan dengan tipe hobby tinggi pada collecting ehavior. Hobby tinggi menggambarkan kolektor yang menyukai segala aktivitas yang dinikmati dan dicari untuk tujuan tertentu seperti mengoleksi piringan hitam yang jarang dilakukan orang lain. Ke-banyakan kolektor piringan hitam memiliki status pendidikan yang tinggi. Dalam Hurlock (1980), diketahui bahwa semakin tinggi pendidikan orang dewasa yang ditempuh, maka minat mereka akan semakin bervariasi. Jika mengoleksi piringan hitam merupakan suatu hobi, maka tidak menutup kemungkinan bahwa kolektor memiliki hobi-hobi lain yang mungkin juga samasama menguras pengeluaran.
Conscientiousness yang tinggi menggambarkan kolektor yang memiliki perilaku rapi, teliti, terorganisir dan lembut dalam mengoleksi, karena piringan hitam adalah benda yang rentan tergores dan penggunaannya lebih rumit dibandingkan dengan media pemutar ehav masa kini yang lebih praktis. Kolektor akan melakukan segala cara untuk dapat memenuhi kebutuhan piringan hitam dan mencurahkan segala perhatian untuk merawat koleksinya. Hal ini didukung dengan pernyataan Belk (1988), bahwa kolektor menampilkan perilaku kompulsif dan gigih dalam memenuhi koleksinya.

Trait Conscientiousness tinggi yang dimiliki kolektor berkaitan dengan tipe passionate tinggi pada collecting ehavior. Passionate tinggi menggambar-kan perilaku kolektor yang sangat terikat dengan benda koleksinya. Diperoleh hasil bahwa penyebaran kepemilikan piringan hitam kolektor beranjak dari 100 hingga lebih 1000 keping. Hal ini menunjukkan bahwa kolektor sudah sangat terikat dengan benda koleksinya dan terus mengumpulkan walaupun jumlahmya sudah sangat banyak. Hal tersebut dilakukan selama bertahuntahun. Bahkan ada yang mengoleksi piringan hitam semenjak remaja. Hal ini bertolak belakang dengan pernyataan Hurlock (1980:259), bahwa segala aktivitas berbentuk rekreasi atau hal yang menimbulkan kesenangan, akan berubah secara ehavio ketika mereka sudah dewasa terlepas apakah sudah berkeluarga ataupun belum. Berbeda dengan kolektor yang tetap mempertahankan aktivitasnya dalam mengoleksi.

Extraversion tinggi menggambar-kan kolektor yang memiliki level aktivitas tinggi yang berorientasi pada kesenangan. McIntosh dan Schmeichel (2004) mengidentifikasi empat ehavio untuk Collecting yang salah satunya adalah untuk mencapai kesenangan. Mengoleksi piringan hitam dapat menimbulkan kesenangan dan kepuasan terhadap kolektor secara subjektif. Walaupun diketahui biasanya 
kolektor lebih menyenangi benda koleksinya dibandingkan orang lain, berbeda dengan kolektor piringan hitam. Kolektor pun banyak mendapatkan koleksinya dengan bersosialisasi dengan banyak orang yang juga mengoleksi, mereka ramah dan mudah bergaul. Hal ini berbeda dengan kolektor benda pada umumnya karena objek koleksi kolektor piringan hitam berkaitan dengan ehav. Musik merupakan hal universal yang banyak digemari oleh setiap orang sehingga kolektor piringan hitam akan lebih mudah dalam bersosialisasi dan menjalin pertemanan.

Agreeableness tinggi meng-gambarkan kolektor memiliki keterikatan emosional dengan koleksi yang dimilikinya yaitu piringan hitam. Faktor agreeableness menggambarkan kolektor yang memiliki hati yang lembut, ehavior al dan mudah tersentuh, kolektor memiliki ketertarikan emosional terhadap benda yang dikoleksinya dikarenakan kolektor menghargai halhal yang memiliki makna. Hal ini didukung dengan hasil analisis Belk (1988) bahwa salah satu traits yang dimiliki kolektor adalah nostalgia.

Neuroticsm rendah menggambarkan kolektor yang memiliki emosi positif yang cenderung akan lebih tenang. Diketahui bahwa ketika kolektor piringan hitam sudah memiliki piringan hitam yang dicari-cari, maka pembelian selanjutnya akan lebih terkendali dengan adanya jeda waktu pembelian. Awalnya diasumsikan kolektor piringan hitam memiliki trait neuroticsm yang tinggi karena kegiatan mengoleksi menimbulkan rasa cemas ketika kolektor tidak dapat memenuhi koleksi yang diidamidamkan. Namun dikarenakan benda koleksi kolektor merupakan piringan hitam yang merupakan media pemutar ehav, yang berarti bahwa kolektor merupakan orang-orang yang menggemari ehav. Kemper dan Danhauer (2005) menjelaskan mengenai ehav, selain dapat meningkatkan kesehatan seseorang juga dapat meringankan dari rasa sakit, perasaan- perasaan dan pikiran yang kurang menyenangkan serta membantu mengurangi rasa cemas. Kolektor piringan hitam memiliki trait neuroticsm yang rendah.

Collecting behavior yang dimiliki kolektor piringan hitam adalah expressive yang tinggi. Tipe expressive menggambarkan dengan mengoleksi mereka dapat mengekspresikan siapa kolektor sesungguhnya dan senang akan perhatian yang didapatkan ketika mengoleksi piringan hitam. Hal ini sesuai dengan pernyataan, "kolektor tertarik untuk mengoleksi sebagai sarana memperkuat diri dengan mendirikan tujuan yang nyata, dapat dicapai, dan memberikan kolektor umpan balik yang konkrit untuk lebih unggul" (McIntosh dan Schmeichel 2004: 87). Dalam Hurlock (1980: 256) dijelaskan bahwa orang dewasa pada umumnya mengetahui benda-benda apa saja yang menjadi ehavi status yang paling dihargai oleh masyarakat di lingkungannya. Sehingga benda-benda tersebut dipandang sebagai bukti keberhasilan ekonomi.

Yang terakhir adalah Inquisitive yang rendah, secara umum kolektor piringan hitam mengoleksi bukan dengan tujuan untuk menjadikan benda koleksinya sebagai suatu investasi dan tidak diperjualbelikan, Belk (1995:94) mengatakan "kolektor sejati" tidak berbasis pada laba. Tujuan investasi ketika memburu koleksi hanya kepentingan sekunder, terlepas dari hal apapun.

Berdasarkan hal tersebut, tipe collecting ehavior yang dimiliki oleh kolektor piringan hitam adalah $\mathbf{P} \uparrow \mathbf{I} \downarrow \mathbf{H} \uparrow \mathbf{E} \uparrow$. Hal ini menggambarkan bahwa kolektor piringan hitam memiliki keterikatan emosional dengan benda koleksi mereka yang dapat menimbulkan kepuasan secara pribadi. Aktivitas mengoleksi merupakan sebuah hobi yang dilakukan karena merupakan aktivitas yang dinikmati dan dicari untuk tujuan tertentu. Lalu mengoleksi merupakan bentuk ekspresi diri. Secara umum kolektor piringan hitam mengoleksi bukan untuk menjadikan benda 
koleksinya sebagai suatu investasi dan tidak untuk diperjualbelikan.

\section{Simpulan}

Pada umumnya kolektor piringan hitam memiliki profil kepribadian Trait Openess to experience tinggi, Counscientiousness tinggi Extraversion tinggi, Agreeableness tinggi, dan Neuroticsm rendah $(\mathbf{O} \uparrow \mathbf{C} \uparrow \mathbf{E} \uparrow \mathbf{A} \uparrow \mathbf{N} \downarrow)$. Tipe ini menggambarkan kolektor yang senang mengeksplorasi halhal yang tidak umum, dengan segala aktivitas mengoleksi yang membutuhkan ketekunan dalam merawat, kegigihan dalam memburu serta terorganisir. Kolektor cenderung lembut hatinya dan sentimentil dengan adanya ikatan emosional terhadap barang koleksi. Mereka mudah bergaul dan bersosialisasi dengan orang lain. Lalu mereka cenderung lebih tenang dan terhindar dari rasa cemas karena kegemaran mengoleksi yang berhubungan dengan musik yang dapat menghilangkan rasa cemas.

Collecting behaviour yang dimiliki kolektor piringan hitam yaitu tipe Passionate tinggi, Insquisitive rendah, Hobby tinggi dan Expressive tinggi $(\mathbf{P} \uparrow \mathbf{I} \downarrow \mathbf{H} \uparrow \mathbf{E} \uparrow)$. Hal ini menggambarkan bahwa secara umum kolektor piringan hitam memiliki keterikatan emosional dengan benda koleksi mereka yang dapat menimbulkan kepuasan secara pribadi. Aktivitas mengoleksi juga merupakan sebuah hobi yang dilakukan karena merupakan aktivitas yang dinikmati dan dicari untuk tujuan tertentu juga sebagai bentuk ekspresi diri. Namun secara umum kolektor piringan hitam mengoleksi bukan untuk menjadikan benda koleksinya sebagai suatu investasi dan bukan untuk diperjualbelikan.

\section{Daftar Pustaka}

Alwisol. 2008. Psikologi Kepribadian (Edisi revisi). Malang: UMM Press

Arikunto, S. 2003. Manajemen Penelitian. Jakarta: PT. Rineka Cipta.
Belk. Russell.W. 1994. Collecting as Luxury Consumption: Effects on Individuals and Households. Journal of Economic Psychology, 16(1995). 477490.

Goldberg, L. R. 1999. A broad-bandwidth, public-domain, personality inventory measuring the lower-level facets of several five-factor models. In I. Mervielde, I. J. Deary, F. De Fruyt, and F. Ostendorf (Eds.), Personality psychology in Europe (Vol. 7, pp. 728).

Hall, Calvin. S. \& Lindzey, G. 1993. Teoriteori Sifat dan Behavioristik. Psikologi Kepribadian 3. Yogyakarta: Kanisius.

Hurlock, Elizabeth. B. 1980. Psikologi Perkembangan. Suatu Pendekatan Sepanjang Rentang Kehidupan. Jakarta: Penerbit Erlangga.

McCrae, R. R., \& Costa, P. T. Jr., (2004). A contemplated revision of the NEO Five-Factor Inventory. Personality and Individual Differences, 36, 587-596.

Mckinley, B. Mark. 2007. The Psychology of Collecting. (http://www.talkingclocks.net/collectin g.pdf). Diunduh pada 10 Februari 2014.

McIntosh, W. D., \& Schmeichel, B. 2004. Collectors and Collecting: A Social Psychological Perspective. Leisure Sciences, 26(1), 85-97.

Miller, Hugh M. Tanpa Tahun. Pengantar Apresiasi Musik (Introduction to Music a Guide to Good Listening). Terjemahan dari Bahasa Inggris oleh Triyono Bramantyo PS.

Muensterberger, W. 1994. Collecting, an unruly passion. Psychological perspectives. Princeton University Press, Princeton.

Noor, Hasanudin. 2009. Psikometri. Aplikasi Dalam Penyusunan Instrumen Pengukuran Perilaku. Bandung: Jauhar Mandiri. 
Pervin. Lawrence. A. \& Cervone. D. 2004. Psikologi Kepribadian. Teori dan Penelitian. Jakarta: Kencana.

Rahmi. S. Ammy. 2012. GAMBARAN TRAIT KEPRIBADIAN PELAKU CYBER BULLYING "Suatu Studi Pada Kelompok Penggemar Penyanyi Korea Ditinjau dari Teori Five Factor Model of Personality Costa dan McCrae". Skripsi: Universitas Islam Bandung. Tidak Diterbitkan.

Santrock. John. W. 2011. Live-Span Development. Perkembangan MasaHidup. Jakarta: Erlangga.

Sedarlah. (2012). Mengoleksi BarangHobi yang Menuntut Keseimbangan. (http://wol.jw.org/en/wol/d/r25/lp- in/102004890). Diunduh pada 20 Maret 2014.

Sugiyono. 2013. Metode Penelitian Kuantitatif, Kualitatif dan $R \& D$. Bandung: Alfabeta.

Sumantri, Suryana. 2012. Perilaku Konsumen: Mengapa Orang Mau Membeli? Jakarta: Quantum Quality International.

Tim Redaksi Depdiknas. 2008. Kamus Besar Bahasa Indonesia (Edisi ke-4). Jakarta: Gramedia.

Yayank. Arie. 2012. Hobi Dan Kepribadian.

(http://warna09.blogspot.com/2013/08/ hobi-dan-kepribadian.html). Diunduh pada $20 \quad$ Maret 2014. 